Dhaka Univ. J. Biol. Sci. 30(1): 105-114, 2021 (January)

\title{
FREQUENCY PERCENTAGE OF SOIL FUNGI AND DIVERSITY OF TRICHODERMA SPP. IN THE RHIZOSPHERE SOIL OF SELECTED VEGETABLE CROP FIELDS
}

\author{
Priyanka BhattacharjeE ${ }^{1}$, Shamim Shamsi* and Md Abul Bashar \\ Department of Botany, University of Dhaka, Dhaka-1000, Bangladesh
}

Key words: Frequency percentage, Soil fungi, Trichoderma spp, Vegetable crops

\begin{abstract}
An attempt was undertaken to detect the soil fungi and diversity of Trichoderma spp in the rhizosphere soil of selected vegetable crops. A total of fifteen fungi viz., Alternaria sp., Aspergillus flavus, A. fumigatus, A. niger, A. ochraceus, Aspergillus sp., Colletotrichum sp., Curvularia sp., Fusarium sp., Mucor sp., Penicillium sp., Rhizoctonia solani, Rhizopus sp., Trichoderma sp. and Syncephalastrum sp. were isolated from rhizospheric soil of brinjal, chili, cucumber, cabbage and onion in Naogaon district. Except Syncephalastrum sp., all the above mentioned fungi including Monilia sp., were isolated from rhizospheric soil of brinjal, cabbage, chili and tomato of Bangladesh Agricultural Research Institute (BARI), Joydebpur, Gazipur. A total of eight types of Trichoderma spp belonging to four species viz., Trichoderma harzianum, T. koningii, T. reesei and $T$. viride were isolated from nine vegetable fields from Naogaon district and BARI. These Trichoderma spp. may be used in the management of soil borne diseases of vegetable crops.
\end{abstract}

\section{Introduction}

The rhizosphere is a micro ecological zone in direct proximity of plant roots. It is functionally defined as the particulate matter and microorganisms that cling to roots after being gently shaken in water. The theoretical extent of the rhizosphere is dependent on the zone of influence of the plant roots and associated microorganisms. The rhizosphere is a metabolically busier, faster moving, more competitive environment than the surrounding soil(1).

The genus Trichoderma is a diverse group of free-living fungi present in soil(27). Trichoderma are characterized by rapid growth and abundant production of conidial spores as well as the capacity to produce sclerotia. These species produce several pigments, ranging from a greenish-yellow up to a reddish tinge, although some colourless specimens are also present. The conidia may also have diverse colouration,

*Author for correspondence: <prof.shamsi@gmail.com>. 1A part of MS thesis of first author.

DOI: https://doi.org/10.3329/dujbs.v30i1.51814 
genus Trichoderma belongs to the phylum Ascomycetes, class Sordariomycetes, order Hypocreales, family Hypocreaceae. The systematics and taxonomy of these fungi have evolved since 1794 when Persoon introduced the name Trichoderma(8). In 1865, Tulasne and Tulasne showed that Hypocrea rufa is the teleomorph of Trichoderma viride Pers ${ }^{(9)}$. Up to 1969 it was reported that within the genus Trichoderma there was only one species, namely $T$. viride(10). Then Rifai distinguished nine "aggregate species" i.e., T. harzianum Rifai, T. viride, T. hamatum (Bonord.) Bainier, T. koningii (Oudem.) Duché \& R. Heim, T. polysporum (Link) Rifai, T. piluliferum J. Webster \& Rifai, T. aureoviride Rifai, T. longibrachiatum Rifai, and T. pseudokoningii Rifai based on morphological characteristics. After that Bissett identified five sections and 27 biological species within the genus Trichoderma ${ }^{(11)}$.These ascomycetous fungi are opportunistic, avirulent, plant symbionts inhabiting in root ecosystems ${ }^{(4,12)}$ but parasites on other groups of fungi(2).

Trichoderma spp. is the most promising and effective antagonistic fungi against several soil borne plant pathogenic fungi(13,14). The advantage of using Trichoderma in controlling soil borne plant pathogens are eco-friendly, effective, ease of mass culturing with less cost of production and growth promoting effect. At present Trichoderma genus is comprised of more than 200 species. Very little information is available about the presence of Trichoderma spp. in the rhizosphere soils of Bangladesh. Hence, the present study was undertaken to find out the frequency percentage of soil fungi and diversity of Trichoderma spp. in the rhizospheric soils of selected vegetable crop fields of BARI, Joydebpur and Naogaon, Bangladesh.

\section{Materials and Methods}

A total of twelve rhizospheric soil samples from twelve locations were collected from four vegetable crop fields viz. cabbage, brinjal, tomato and chili of BARI, Joydebpur, Gazipur. Another six soil samples from six locations were collected from six vegetable crop fields viz. brinjal, chili, cucumber, cabbage, tomato and onion from Naogaon district. The samples were collected between the months of April 2018 to May 2019. Soil samples were collected from a depth of $15 \mathrm{~cm}$ and kept into sterilized cellophane bags ${ }^{(18)}$. Fungi associated with soil samples were isolated individually following Serial dilution technique ${ }^{(19)}$.

Collected soil samples were air dried and ground into powder. At first $1.0 \mathrm{~g}$ soil was added to $99 \mathrm{ml}$ of distilled water in a conical flask and mixed it very well with a glass rod and marked as mother suspension. Then five test tubes each containing $9 \mathrm{ml}$ sterilized distilled water were taken. $1 \mathrm{ml}$ of mother suspension was added into the $1^{\text {st }}$ test tube and made it $10 \mathrm{ml}$. Then it was mixed well, $1 \mathrm{ml}$ of the suspension from the $1^{\text {st }}$ test tube was added into the $2^{\text {nd }}$ test tube and made it $10 \mathrm{ml}$. This process was performed for rest of the test tubes and diluted the mother suspension 10, 100, 1000, 10000 and 100000 times. 
For each dilution, $1 \mathrm{ml}$ of suspension was poured into a sterilized Petri plate and then about $15 \mathrm{ml}$ of sterilized melted PDA medium (about $50^{\circ} \mathrm{C}$ ) was added. One drop of Lactophenol solution was added to $15 \mathrm{ml}$ medium for preventing bacterial growth, before pouring into Petri plates. The plate was moved gently on the Laminar air flow table to get a homogenous distribution of the suspension. Five replications were maintained for each dilution. All the Petri plates were incubated into $25 \pm 2^{\circ} \mathrm{C}$ temperature. After 3 days, individual fungal colonies belonging to the genera Rhizoctonia and Trichoderma were subcultured on PDA slants randomly, from the culture plates and stored at $4^{\circ} \mathrm{C}$ in an incubator for future studies.

Population density expressed in terms of Colony Forming Unit (CFU) per gram of soil with dilution factors. The per cent frequency of each isolate was calculated by

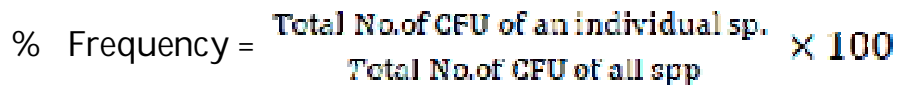

Identities of soil fungi were determined following the standard literature ${ }^{(16-18)}$. Detail morphological studies of the fungal isolates were made in order to determine their identity. For microscopic observations fungal structures like mycelia, spore bearing structures and spores were scrapped off from the surface with a scalpel or picked up with a needle and was mounted in lacto phenol over a clean slide. In case of hyaline structures, a little amount of cotton blue was added to the mounted fluid. A clean cover glass was placed over the material. Excess fluid was removed by shaking with blotting paper and examined under microscope. The microscopic structural view of the fungi was taken by a digital camera. All the specimens, included in the present study were preserved in the slant at $4-10^{\circ} \mathrm{C}$ in refrigerator in the Mycology and Plant Pathology Laboratory, Department of Botany, University of Dhaka, Bangladesh.

Antagonistic fungal colony had key characteristics that was used to identify them as Trichoderma, including growth pattern, growth rate and colour. Species level identification of Trichoderma isolates was done based on colony colour, formation of chlamydospores, conidiophores, phialide characters and shape of conidia (19-21). Isolated Trichoderma types were divided into several types according to their vegetable field of BARI and Naogaon district.

\section{Results and Discussion}

In Naogaon district, a total of fifteen fungi were isolated from rhizospheric soil of brinjal, chili, cucumber, cabbage and onion. They were Alternaria sp., Aspergillus sp., A. flavus, A. fumigatus, A. niger, A. ochraceus, Colletotrichum sp., Curvularia sp., Fusarium sp., Mucor sp., Penicillium sp., Rhizoctonia solani, Rhizopus sp., Trichoderma sp. and Syncephalastrum sp. (Table 1). 
Table 1. Frequency percentage of fungi associated with rhizospheric soil of vegetable crop fields of Naogaon district.

\begin{tabular}{|c|c|c|c|c|c|c|}
\hline \multirow[t]{2}{*}{ Name of fungi } & \multicolumn{6}{|c|}{$\begin{array}{l}\text { Frequency percentage of fungi in rhizospheric soil of different } \\
\text { vegetables }\end{array}$} \\
\hline & Brinjal & Cabbage & Chili & Cucumber & Onion & Tomato \\
\hline Alternaria sp. & 1.39 & 19.23 & 14.20 & 10.22 & 21.55 & 12.28 \\
\hline Aspergillus sp. & - & - & - & - & 14.37 & 12.86 \\
\hline Aspergillus flavus & 1.39 & 12.18 & 13.11 & 1.70 & - & 1.17 \\
\hline A. fumigatus & 13.98 & 7.69 & 4.37 & - & - & 26.90 \\
\hline A. niger & 24.47 & - & 19.67 & 18.75 & 30.38 & 6.43 \\
\hline A. ochraceus & - & - & 4.36 & - & - & 0.58 \\
\hline Colletotrichum sp. & - & 14.11 & 0.55 & 19.89 & - & - \\
\hline Curvularia sp. & 2.09 & & 14.75 & & 9.95 & 5.85 \\
\hline Fusarium sp. & 13.99 & 17.95 & 11.48 & 13.99 & - & 1.75 \\
\hline Mucorsp. & 4.89 & - & - & - & - & 3.50 \\
\hline Penicillium sp. & 10.48 & & 1.63 & 1.14 & - & 2.92 \\
\hline Rhizoctonia solani & - & - & - & - & 7.73 & 21.6 \\
\hline Rhizopus sp. & 4.89 & - & - & 17.05 & - & - \\
\hline Syncephalastrum sp. & 1.39 & - & - & - & - & - \\
\hline Trichoderma sp. & 4.88 & 3.21 & 3.27 & 3.21 & - & 1.75 \\
\hline
\end{tabular}

'-' represents absence of respective fungi.

On the other hand, a total of 15 fungi were isolated from rhizospheric soil of brinjal, cabbage, chili and tomato collected from BARI, Joydebpur, Gazipur. They were Alternaria sp., Aspergillus flavus, A. fumigatus, A. niger, A. ochraceus, Aspergillus sp., Colletotrichum sp., Curvularia sp., Fusarium sp., Monilia sp., Mucor sp., Penicillium sp., Rhizoctonia solani, Rhizopus sp. and Trichoderma sp. (Table 2).

Among the isolated soil fungi, Trichoderma spp. were selected as antagonistic fungi due to their novel biological control activity against notorious pathogens. Taxonomic identification of eight different isolates of Trichoderma spp. up to species level were done based on colony morphology and microscopic observation by using compound microscope (Table 3, Figs 1-3). 
Table 2. Frequency percentage of fungi associated with rhizospheric soil of vegetable crop fields of BARI, Joydebpur, Gazipur.

\begin{tabular}{lcccc}
\hline \multirow{2}{*}{ Name of fungi } & \multicolumn{4}{c}{ Frequency percentage of fungi in rhizospheric soil of different } \\
& Brinjal & Cabbage & Chili & Tomato \\
\cline { 2 - 5 } & - & 20 & 16.66 & 10.73 \\
\hline Alternaria sp. & 12.96 & 12.41 & 5.56 & 13.66 \\
Aspergillus sp. & - & 10.34 & 16.67 & - \\
Aspergillus flavus & 14.81 & 4.83 & 4.32 & - \\
A. fumigatus & 20.37 & 0.69 & 7.41 & 23.41 \\
A. niger & - & 1.37 & 7.43 & - \\
A. ochraceus & - & 15.17 & 1.23 & - \\
Colletotrichum sp. & - & 1.40 & 10.49 & 10.73 \\
Curvularia sp. & 18.51 & 20.69 & 7.41 & - \\
Fusarium sp. & 3.70 & - & 0.62 & - \\
Monilia sp. & 1.85 & 0.70 & - & 4.39 \\
Mucor sp. & 5.56 & 1.39 & - & 4.38 \\
Penicillium sp. & - & - & - & 21.97 \\
Rhizoctonia solani & 11.11 & - & - & - \\
Rhizopus sp. & 9.26 & 2.76 & - & 8.78 \\
Trichoderma sp. & & &
\end{tabular}

'-' represents absence of respective fungi.

Trichoderma harzianum Rifai, Mycological Papers 116: 38 (1969)

Isolate type-7, colony showed light greenish producing tufts or pustules fringed by sterile white mycelium, colony reverse showed dull yellowish. Conidiophores showed frequent branching and were verticillate. Phialides were ampulliform and convergent. Conidia were sub-globose to ovoid shape. Formation of chlamydospore was infrequent and produced terminally and intercalary. Based on these characters this isolate was identified as Trichoderma harizanum (Figs 1A and 2A ).

Specimen examined: Isolates were from rhizospheric soil of damping off brinjal field, Naogaon district. Priyanka Bhattacharjee 11, 8 October 2018.

Trichoderma koningii Oudem., Archives Néerlandaises 7: 291 (1902)

Isolates type-1, type- 2 and type-3 colony showed dull green to bluish green sporulation. Colony reverse was colourless to pale yellow. Conidiophores were broad or 
narrow, verticillate branching frequently. Phialides showed lageniform or ampulliform, shape divergent and terminal phialide more elongated. Conidia shape was sub cylindrical to narrow ellipsoidal. Formation of chlamydospore was infrequent or frequently producing intercalary and terminally. Based on these characters the isolates were identified as Trichoderma koningii. They were classified into Trichoderma koningii 1, T. koningii 2 and T. koningii 3 (Figs 1B-D and 2B-D).

Table 3. Morphological and microscopic characteristics of Trichoderma spp.

\begin{tabular}{|c|c|c|c|c|c|c|}
\hline $\begin{array}{l}\text { Sl. } \\
\text { No. }\end{array}$ & Isolate & $\begin{array}{l}\text { Colony } \\
\text { colour }\end{array}$ & $\begin{array}{l}\text { Colony } \\
\text { reverse } \\
\text { colour }\end{array}$ & $\begin{array}{l}\text { Conidiophore } \\
\text { character }\end{array}$ & $\begin{array}{l}\text { Phialide } \\
\text { character }\end{array}$ & $\begin{array}{l}\text { Conidia } \\
\text { shape }\end{array}$ \\
\hline 1 & Type 1 & $\begin{array}{l}\text { Dull green to } \\
\text { bluish green }\end{array}$ & $\begin{array}{l}\text { Colour } \\
\text { less }\end{array}$ & $\begin{array}{l}\text { Broad, } \\
\text { frequent } \\
\text { branching }\end{array}$ & $\begin{array}{l}\text { Terminal } \\
\text { phialide more } \\
\text { elongated }\end{array}$ & $\begin{array}{l}\text { Cylindrica } \\
1 \text { to } \\
\text { ellipsoidal }\end{array}$ \\
\hline 2 & Type 2 & $\begin{array}{l}\text { Dull green to } \\
\text { bluish green }\end{array}$ & $\begin{array}{l}\text { Pale } \\
\text { yellowish }\end{array}$ & $\begin{array}{l}\text { Broad, } \\
\text { verticillate, } \\
\text { frequent } \\
\text { branching }\end{array}$ & Cylindrical & Globose \\
\hline 3 & Type 3 & Bluish green & Colourless & $\begin{array}{l}\text { Broad, } \\
\text { frequent } \\
\text { branching }\end{array}$ & $\begin{array}{l}\text { Sub cylindrical to } \\
\text { narrow } \\
\text { ellipsoid }\end{array}$ & Globose \\
\hline 4 & Type 4 & $\begin{array}{l}\text { Scattered in } \\
\text { minute tufts, } \\
\text { pale yellow } \\
\text { green }\end{array}$ & $\begin{array}{l}\text { Pale } \\
\text { yellowish }\end{array}$ & $\begin{array}{l}\text { Rarely } \\
\text { branched }\end{array}$ & $\begin{array}{l}\text { Cylindrical or } \\
\text { slightly inflated, } \\
\text { divergent }\end{array}$ & Ellipsoidal \\
\hline 5 & Type 5 & $\begin{array}{l}\text { Dark green } \\
\text { producing } \\
\text { tufts or } \\
\text { pustules } \\
\text { fringed by } \\
\text { sterile white } \\
\text { mycelium }\end{array}$ & $\begin{array}{l}\text { Dull } \\
\text { yellowish }\end{array}$ & $\begin{array}{l}\text { Frequent } \\
\text { branching }\end{array}$ & $\begin{array}{l}\text { Ampulliform, } \\
\text { convergent }\end{array}$ & $\begin{array}{l}\text { Sub } \\
\text { globose to } \\
\text { ovoid }\end{array}$ \\
\hline 6 & Type 6 & $\begin{array}{l}\text { Dark bluish } \\
\text { green }\end{array}$ & $\begin{array}{l}\text { Colour } \\
\text { less }\end{array}$ & $\begin{array}{l}\text { Infrequent } \\
\text { branching, } \\
\text { verticillate }\end{array}$ & Convergent & $\begin{array}{l}\text { Globose to } \\
\text { ellipsoidal }\end{array}$ \\
\hline 7 & Type 7 & Bluish green & $\begin{array}{l}\text { Colour } \\
\text { less }\end{array}$ & $\begin{array}{l}\text { Infrequent } \\
\text { branching }\end{array}$ & Convergent & $\begin{array}{l}\text { Globose to } \\
\text { ellipsoidal }\end{array}$ \\
\hline 8 & Type 8 & $\begin{array}{l}\text { Dark green, } \\
\text { Scattered in } \\
\text { minute tufts }\end{array}$ & $\begin{array}{l}\text { Colour } \\
\text { less }\end{array}$ & $\begin{array}{l}\text { Rarely } \\
\text { branched, } \\
\text { verticillate }\end{array}$ & $\begin{array}{l}\text { Cylindrical or } \\
\text { slightly inflated, } \\
\text { divergent }\end{array}$ & $\begin{array}{l}\text { Globose to } \\
\text { ellipsoidal }\end{array}$ \\
\hline
\end{tabular}


Specimen examined: Isolate type 1 from damping off rhizospheric soil of chili field, Naogaon district. Priyanka Bhattacharjee 17, 9 September 2018, type 2 from damping off rhizospheric soil of chili field. Naogaon district. Priyanka Bhattacharjee 29, 16 October 2018 and type 3 from damping off rhzospheric soil of brinjal field. BARI, Gazipur district. Priyanka Bhattacharjee 43, 8 February 2019.
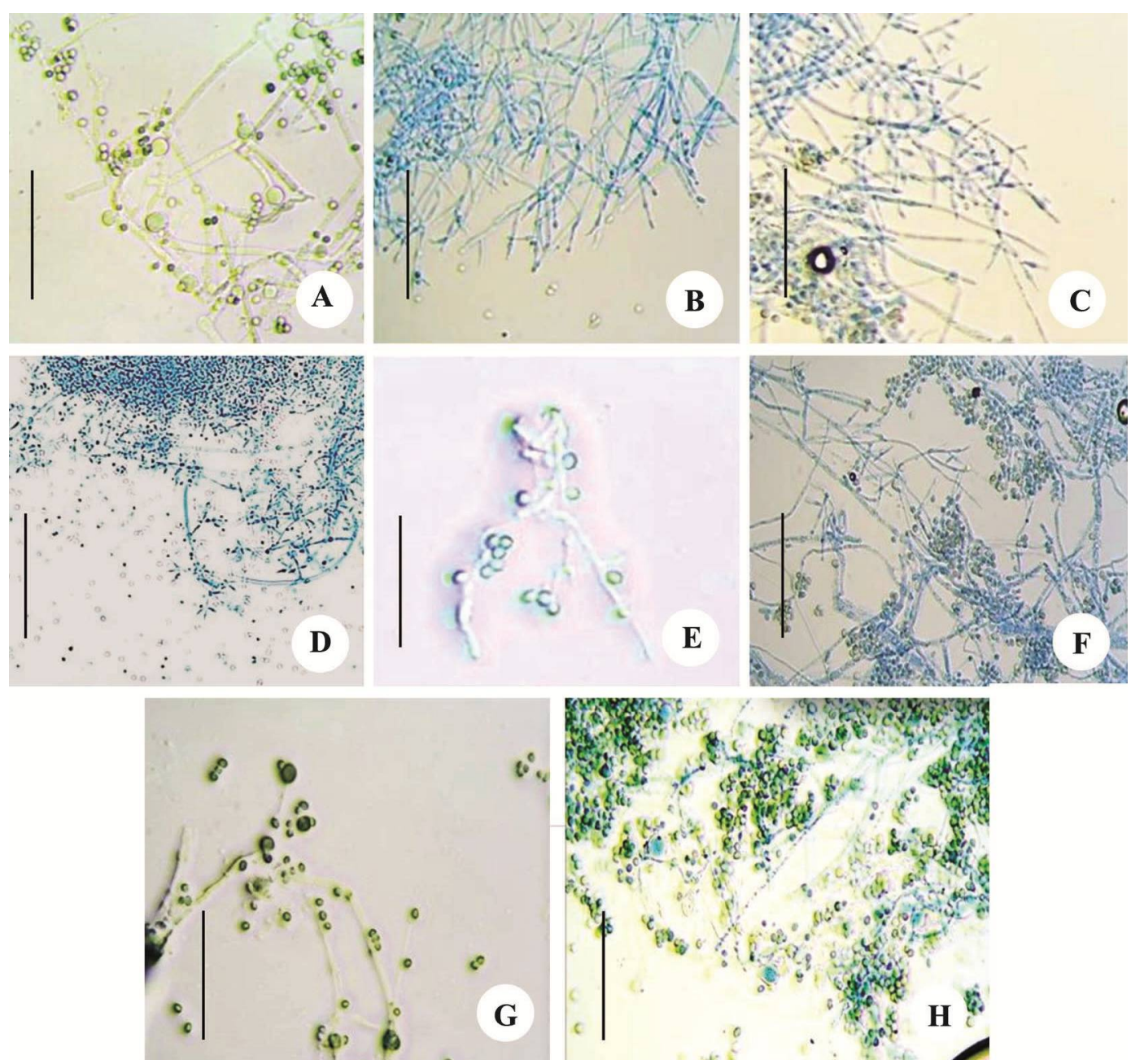

Fig. 1. Conidiophores, phialides and conidia of different isolates of Trichoderma spp. A Trichoderma harzianum, B. T. koningii type 1, C. T. koningii type 2, D. T. koningii type 3, E. T. reesei, F. T. viride type 5, G. T. viride type 6, and H. T. viride type 8 . $($ Bar $=50 \mu \mathrm{m})$.

Trichoderma reesei Simmons EG (1977) in Bigelow \& Simmons, Abstracts, 2nd International Mycological Congress (Tampa) 2: 618. 

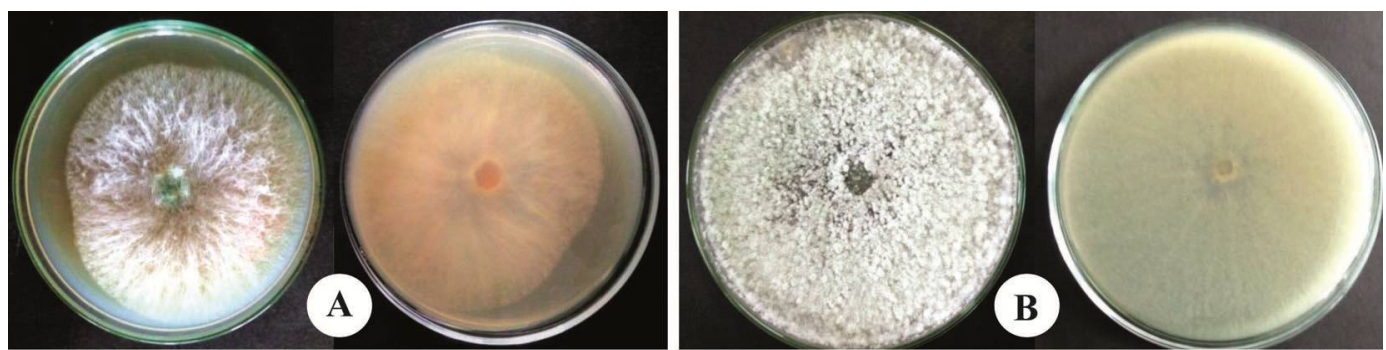

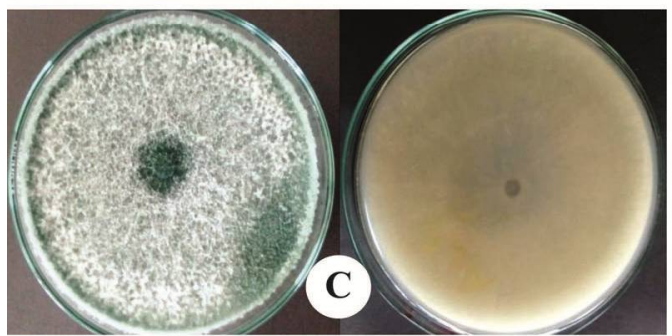

Front side

\section{Reverse side}

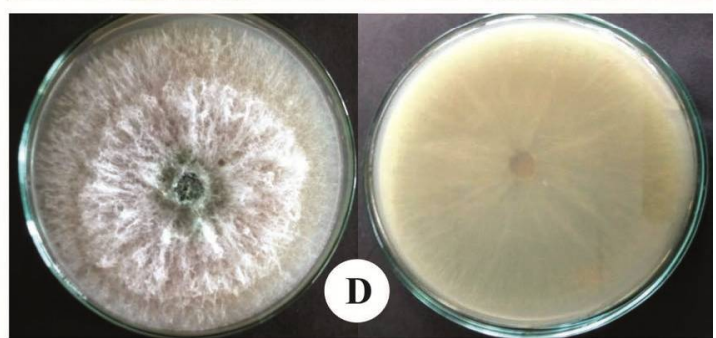

Front side

Reverse side

Plate 1. Colonies show front and reverse side of different isolates of Trichoderma spp. on PDA medium after $5^{\text {th }}$ day of inoculation. A. T. harzianum type 7, B. T. koningii type 1, C. T. koningii type 2 and $T$. koningii type 3 .
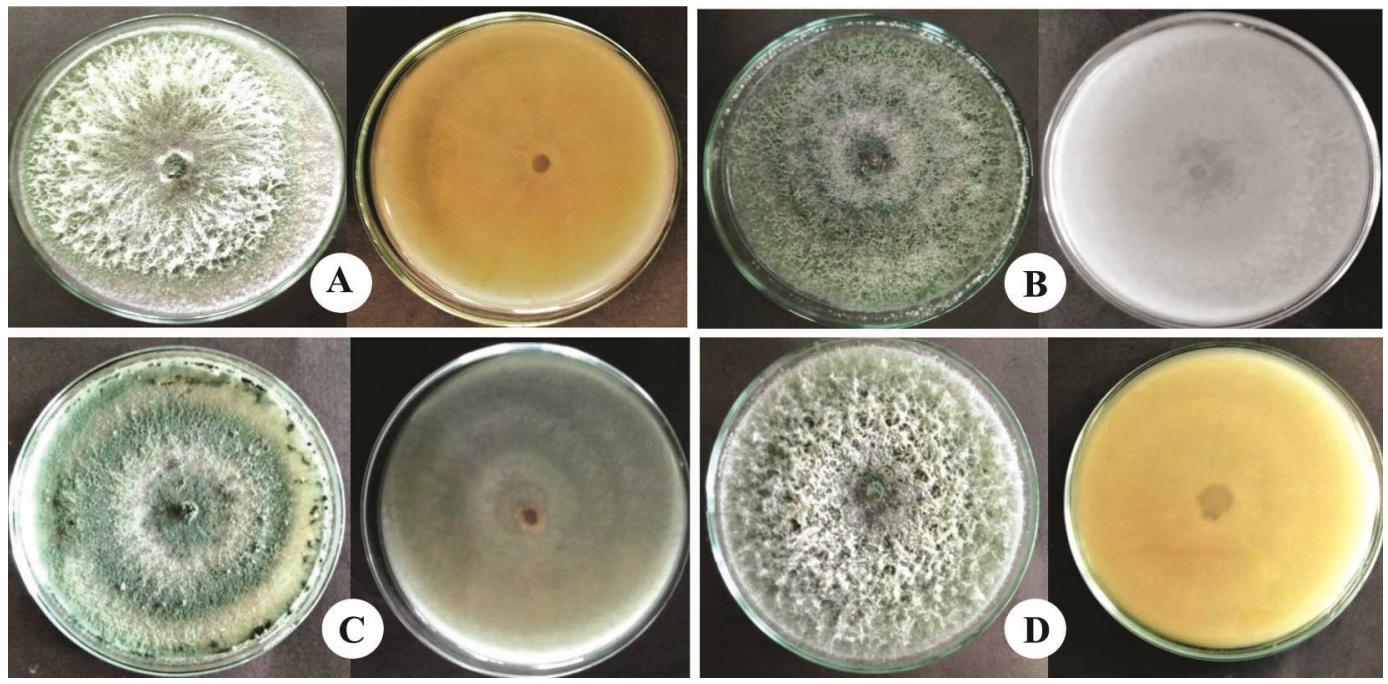

Plate 2. Colonies show front and reverse side of different isolates of Trichoderma spp. on PDA medium after $5^{\text {th }}$ day of inoculation. A. T. reesei type 4 , B. Trichoderma viride type $5, C$. T. viride type 6, and D. T. viride type 8 .

Colony of isolate type 4 showed scattered minute tufts, pale yellowish-green in colour, colony reverse was pale yellowish. Conidiophores were rarely branched and verticillate. Phialides shape were cylindrical or slightly inflated and divergent phialides. Conidia shape was ellipsoidal. Chlamydospore was frequently produced both terminally 
and intercalary. Based on these characters this isolate was identified as Trichoderma reesei (Fig. 1E and 3A).

Specimen examined: Isolate type 4 from damping off rhizospheric soil of tomato field. BARI Gazipur district. Priyanka Bhattacharjee 67, 17 October 2019.

Trichoderma viride Pers., Neues Magazin für die Botanik 1: 92 (1794)

Isolates type-5, type- 6 and type-8, colony showed dark green to dark bluish green sporulation, colony reverse was amber or colourless. Conidiophore usually long, infrequently branched, verticillate conidiophores. Phialides were frequently paired, convergent. Conidial shape was globose to ellipsoidal. Formation of chlamydospore was infrequent or frequently produced terminally and intercalary. Based on these characters these isolates were identified as Trichoderma viride 1, T. viride 2 and T. viride 3 (Fig. 1F-H and 3B-D).

Specimen examined: Isolates type 5 from damping off rhizospheric soil of cabbage field, BARI Gazipur district. Priyanka Bhattacharjee 81, 19 November 2019. Type 6 from damping off rhizospheric soil of chili field, Naogaon district. Priyanka Bhattacharjee 55, 11 October 2019 and type 8 from damping off rhizospheric soil of tomato field, BARI Gazipur district. Priyanka Bhattacharjee 58, 11 October 2019.

Trichoderma spp. isolated and identification in the present investigation may be used in the management of soil borne diseases of vegetable crops.

\section{Acknowledgement}

The first author gratefully acknowledges the financial support by the Ministry of Science and Technology, Government of the People's Republic of Bangladesh through NST fellowship.

\section{References}

1. Kumar V,M Shahid, M Srivastava, P Sonika, A Singh A and A Sharma 2014. Role of secondary metabolites produced by commercial Trichoderma spp. and their effect against soil borne pathogens. Biosensors 03(01): 1-5.

2. Samuels GJ 1996. Trichoderma: A review of biology and systematics of the genus. Myco Res 100(8): 243-250.

3. Harman GE,CR Howell, A Viterbo, I Chet and M Lorito 2004. Trichoderma spp. opportunistic, avirulent plant symbionts. Nature Rev Microbial. 2(1): 43-56.

4. Schuster A and M Schmoll 2010. Biology and biotechnology of Trichoderma. App Microbiol Biotechnol. 87(3): 787-799.

5. Matei S,GM Matei, P Cornea and G Popa 2011. Characterization of soil Trichoderma isolates for potential biocontrol of plant pathogens. Factori şi procese pedogenetice din zona temperate 10: 29-37. 
6. Mutia D and F Prilya 2017. Exploration of Trichoderma spp. and fungal pathogen that causes a strawberry anthracnose and examination of in vitro antagonistic activity. Biotika, 5(18): 58-68.

7. Mohan PN 2017. Studies on antagonistic potential of Trichoderma spp. from saline soils. Agricultural University 32: 717-724.

8. Persoon CH. 1794. Disposita methodica fungorum. Römer's Neues Mag Bot. 1: 81-128.

9. Tulasne LR, Tulasne C. Selecta fungorum carpologia. Vol. 3 Paris: Paris Museum; 1865.

10. Bisby 1939. Antagonistic properties of species-groups of Trichoderma: II. Production of volatile Antibiotic. Trans. Brit. Myco. Soc. 57(1): 41-4

11. Bissett J 1991. A revision of the genus Trichoderma. II. Infrageneric classification. Can J Bot. 69: 2357-2372.

12. Digamber PS 2017. Geographical diversity analysis of Trichoderma spp. isolates based on sequence related amplified polymorphism (SRAP) marker. M.Sc. Thesis. College of Agricultural Biotechnology, Latur. India

13. Kumari R, HK Yadav, YK Bhoon and A Varma 2013. Colonization of cruciferous plants by Piriformospora indica. Current Science 85: 1672-1674.

14. Kucuk C and M Kivanc 2004. In vitro antifungal activity of strains of Trichoderma harzianum. Turk. J. Biol. 28: 111-115.

15. Thom C and KB Raper 1945. A Manual of the Aspergilli. The Williams \& Wilkins Company. Baltimore. pp. 373.

16. Raper KB and C Thom 1949. A Manual of the Penicillium. The Willium and Wilkins. Company, Baltimore, USA. pp. 875.

17. Gilman JC 1967. A Manual of Soil Fungi. Oxford and IBH Pub. Co., New Delhi, 2nd Edn. (Revised). pp. $x+450$.

18. Bissett J 1992. Trichoderma atroviride. Can. J. Bot. 70: 639 - 641.

19. Bissett J, G Szakacs, CA Nolan, I Druzhinina, CM Kullnig-Gradinger and CP Kubicek 2003. Seven new taxa of Trichoderma from Asia Can. J. Bot. 81: 570-586.

20. Barnett HL and BB Hunter 1972. Illustrated Genera of Imperfect Fungi. 3rd Edition, Burgess Publishing Co., Minneapolis, pp. 241

21. Virdiana I, M Rahmaningsih, B Forster, JF. Peter and DS Caligari 2019. Trichoderma : a Manual. Oxford Publisher: CAB International. 